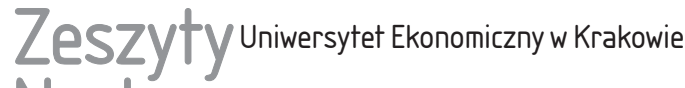 Naukowe
}

$8(944)$

ISSN 1898-6447

Zesz. Nauk. UEK, 2015; 8 (944): 57-67 DOI: 10.15678/ZNUEK.2015.0944.0805

Justyna Pawlak

Katedra Psychologii i Dydaktyki

Uniwersytet Ekonomiczny w Krakowie

\section{Podmiotowość i partycypacja pracowników a zaangażowanie i odpowiedzialność w zespole w sytuacji zmiany*}

\section{Streszczenie}

Współczesne rynki wymagają, aby przedsiębiorstwa stały się organizacjami stale przekształcającymi się, a zatem takimi, które będą potrafiły przewidzieć kierunek nadchodzących zmian i się do nich dostosowywać. Jest to wyzwanie zarówno dla menedżerów, jak i dla szeregowych pracowników, u których może pojawić się opór przed zmianami. Celem artykułu jest wykazanie, w jaki sposób zwiększenie poczucia podmiotowości i partycypacji pracowników może pomóc w akceptacji zmiany dzięki wzrostowi zaangażowania i odpowiedzialności zespołu. Każda grupa pracujących razem ludzi podlega określonym etapom rozwoju oraz tendencjom, które wpływają na jego spójność i efektywność. Zarządzanie przez partycypację, kładąc nacisk na podmiotowość pracownika, wzmacnia zaangażowanie, a zwiększając poczucie kontroli, zmniejsza lęk przed zmianą. Tworzy też kulturę organizacji, w której członkowie zespołu mogą pomóc sobie nawzajem w radzeniu z koniecznością nieustannego dostosowywania się.

Słowa kluczowe: zarządzanie przez partycypację, zaangażowanie, praca zespołowa, implementacja zmiany.

* Artykuł powstał w ramach realizacji tematu badawczego finansowanego ze środków przyznanych Wydziałowi Ekonomii i Stosunków Międzynarodowych Uniwersytetu Ekonomicznego w Krakowie w ramach dotacji na utrzymanie potencjału badawczego. 


\section{Wprowadzenie}

Jednym z najważniejszych zadań współczesnych organizacji, które chcą przetrwać czy to na lokalnym, czy międzynarodowym rynku, jest tworzenie przewagi konkurencyjnej. Aby to osiągnąć, z jednej strony muszą one nieustannie śledzić rynek, zmieniające się potrzeby klientów, rozwój konkurencji, nowych technologii oraz trendów, a następnie dostosowywać się do nich, natomiast z drugiej strony muszą poszukiwać coraz efektywniejszych sposobów zarządzania personelem, które pozwolą im zwiększać motywację i zaangażowanie pracowników, jak najlepiej wykorzystywać ich potencjał, a równocześnie pomagać im lepiej sobie radzić ze zmianami wynikającymi z konieczności nieustannej elastyczności i dostosowywania się. Jak się bowiem okazuje, we współczesnym, turbulentnym otoczeniu paradoksalnie to zmiana jest dla przedsiębiorstwa jedynym stałym elementem działania.

Połączenie tych dwóch zadań jest dużym wyzwaniem, gdyż implementacja zmian związana jest zawsze z ryzykiem. Jednym z jego wymiarów, nie zawsze branym pod uwagę przez management, jest wprowadzenie zmian, które nie są akceptowane przez pracowników, lub zmian, które są pozornie akceptowane i budzą w zatrudnionych opór. Jak pisze M. Kruszewska [2004, s. 98], „każda zmiana wywołuje naturalny opór pracowników. Błędy w komunikacji między zarządem a podwładnymi mogą pogrążyć firmę równie szybko, jak brak ciągłego dostosowywania się do otoczenia”. Szczególną rolę w reakcji pracowników na konieczność zmiany pełnią zespoły, które mogą być albo wsparciem dla pojedynczych pracowników, albo też, poprzez wzajemny wpływ, mogą zwielokrotnić efekt oporu. Należy bowiem pamiętać, jak podkreśla K. Blanchard [2007], że zespoły, w zależności od swojej spójności i relacji między pracownikami, mogą zarówno zwiększać, jak i zmniejszać morale oraz wydajność pracowników. Dlatego też istotne jest zidentyfikowanie czynników, które sprzyjają zwiększeniu gotowości zespołu do zaakceptowania zmian, a także wzrostowi zaangażowania i podejmowania odpowiedzialności, wspierając tym samym organizację w elastycznym dopasowywaniu się do kapryśnych warunków panujących na rynkach. Wychodząc zatem naprzeciw potrzebom doprecyzowywania optymalnych psychologicznych warunków pracy, w tym tak istotnej obecnie pracy zespołowej, niniejszy artykuł ma na celu ukazanie związku pomiędzy poczuciem podmiotowości partycypacji pracowników a zaangażowaniem i podejmowaniem odpowiedzialności w zespole w warunkach zmiany. 


\section{Pracownik w sytuacji zmiany}

W najbliższych latach przedsiębiorstwa muszą być organizacjami stale przekształcającymi się, a więc takimi, które potrafią zarówno przewidzieć kierunek zmian, jak i też szybko zaadaptować się do nich. Aby jednak wprowadzić jakąkolwiek zmianę, potrzebna jest zmiana na poziomie myślenia i zachowania wszystkich uczestników tego procesu: pracowników i zarządzających. Dużym błędem w przygotowaniu i implementacji zmiany jest ignorowanie ludzkich poglądów, wartości, a także postaw wobec zmian [Kruszewska 2004, Kupczyk, Korolewska-Mróz i Czerwonka 1998]. Nawet rekrutowanie personelu spośród młodych ludzi, deklarujących otwartość na zmiany, nie daje gwarancji, że gdy pojawi się konieczność reorganizacji dotychczasowego sposobu działania, nie pojawi się opór. M. Hammer, jeden z twórców reengineeringu, podkreślał zasadnicze znaczenie, jakie odgrywa czynnik ludzki, stwierdzając: ,nie byłem dość biegły w tym przedmiocie, co wynikało z mojego inżynierskiego wykształcenia. Nie doceniałem wymiaru ludzkiego tak, jak na to zasługuje. Teraz już wiem, że to on jest decydujący" [Brilman 2002, s. 277]. Mimo zmieniających się czasów, zmiany postrzegania przez człowieka swojego miejsca i roli zastanych warunków [Taylor 1995], a także coraz większego przyzwolenia na zmianę i wzrost znaczenia elastyczności, nadal jednak konieczność porzucenia dotychczasowego sposobu działania budzi u większości osób lęk i niechęć [Toffler 1998]. Prowadzą one do - czasem być może nawet nieświadomego - oporu, który skutecznie może blokować efektywną implementację i możliwe korzyści płynące ze zmiany. Zdaniem P. Lawrence’a [2008] opór wobec zmian może przybierać różne formy, np. pogorszenie wyników pracy, rezygnację z pracy w danym zespole, chroniczne konflikty, wrogość, zwalnianie tempa pracy, a także głośne wyrażanie pseudologicznych powodów, że w wyniku planowanych zmian nie osiągnie się oczekiwanych rezultatów. Oprócz lęku przed zmianą pojawiają się także inne przyczyny stawiania oporu przez pracowników wobec innowacji, np. niezrozumienie i brak zaufania, obawa przed utratą jakiejś wartości oraz że zmiana będzie się wiązała z koniecznością nabycia nowych, subiektywnie trudnych do osiągniecia kompetencji, poczucie presji, błędy przełożonych itp. [Schlesinger i in. 1999].

Poradzenie sobie z niechęcią wobec zmian i dotarcie do jej przyczyn wymaga od kadry kierowniczej podjęcia konkretnych działań, gdyż próba „przeczekania” niechęci lub wprowadzanie zmian na siłę będzie miała nieuchronnie niekorzystne skutki dla jakości i efektywności pracy. Warto zdawać sobie sprawę i przekonać o tym personel, że każda kolejna umiejętność, każda próba sensownego dostosowania się do zmieniających się okoliczności budują kapitał pracownika i poszerzają jego kompetencje. Jak stwierdza A. Kleiner, organizacje odpowiedzialne za swoich pracowników, powinny pomóc im w gromadzeniu różnego 
rodzaju kapitałów, nie tylko finansowego, związanego z comiesięczną wypłatą. Dzięki takim działaniom firmy cementują lojalność, identyfikują ludzi z celami przedsiębiorstwa i budują silniejszą firmę [Kleiner 2003, s. 29]. Wśród taktyk skutecznych w dłuższej perspektywie, które ułatwiają akceptację zmian, P.F. Schlesinger i współautorzy wymieniają: dobrą komunikację, wsparcie i partycypację. Wszystkie te czynniki stanowią ważne składniki podmiotowego podejścia do pracowników.

\section{Podmiotowe podejście do pracowników i zarządzanie przez partycypację a otwartość na zmiany}

Aby zapewnić warunki pracy zachęcające do pełnego zaangażowania, gotowości do współpracy, skutecznej komunikacji, zaufania i wynikającej z nich otwartości na zmianę, konieczne jest takie stworzenie kultury organizacyjnej, która będzie szanowała podmiotowość pracowników [Podmiotowość człowieka... 2012]. Wiąże się to przede wszystkim z postrzeganiem pracownika nie tylko jako jednego z zasobów, którymi dysponuje dana organizacja, ale jako osoby. Oznacza to między innymi otwarcie na dialog, zachęcanie do krytycznego myślenia i analizowania zadań, przyzwolenie na kreatywność oraz zaproszenie do partycypacji. W konsekwencji można się spodziewać, że wzrośnie zaangażowanie pracowników i ich gotowość do akceptacji zmian, nawet tych, które budzą ich obawy. Podmiotowe traktowanie personelu wpływa także na gotowość do wzięcia odpowiedzialności za wyniki działań nie tylko w ramach swojego wąsko rozumianego miejsca pracy, ale i w szerszym kontekście, gdyż ,pracownik upodmiotowiony celowymi zabiegami swojej firmy sam staje się społecznie odpowiedzialny" [Zbiegień-Maciąg 2005, s. 132]. Zatem wzmacnianie poczucia podmiotowości pracowników, czyli poczucia bycia autorem własnego życia i osobą odpowiedzialną za własne decyzje i zachowania, a nie zaledwie reagującą na to, co się przydarza, zwiększa ich poczucie wpływu. Z kolei dzięki zyskaniu poczucia kontroli z jednej strony wzrasta gotowość do zaangażowania i odpowiedzialności za wykonywane zadania, gdyż jednostka postrzega swoją pracę jako własny wybór, a nie narzuconą z zewnątrz konieczność, a z drugiej zmniejsza się stres i lęk przed zmianą [Folkman i Lazarus 1998]. Jak wykazały badania, wykonywanie pracy w warunkach umożliwiających sprawowanie kontroli osłabia rozwój odczuwanego napięcia [Karasek i Theorell 1990, Dudek, Merecz i Makowska 2001].

Możliwość doświadczania własnej podmiotowości w miejscu pracy zwiększa zatem efektywność, gdyż pozwala na uaktywnianie się motywacji zaangażowania wewnętrznego i determinuje gotowość do podejmowania wysiłku oraz decyduje o tym jak długo i jak intensywnie udostępniać on będzie organizacji swoje zasoby 
jako kapitału ludzkiego. Ten ostatni czynnik szczególnie jest istotny w przypadku pracy zespołowej, w której konieczna jest otwartość na współpracowników i gotowość dzielenia się swoim know how (por. [Pawlak 2014]). Wzmacnianie poczucia podmiotowości przekłada się zatem również na funkcjonowanie zespołów w organizacji, gdyż ich członkowie, oprócz nastawienia do pracy, zmieniają też nastawienie do siebie nawzajem, stając się dla siebie źródłem wsparcia.

Zdaniem J. Penca [1998] pracownicy osiągają dobre wyniki, nie dzięki wykonywaniu odgórnych, nawet najtrafniejszych poleceń, ale przede wszystkim dzięki własnemu zaangażowaniu, najlepszym zaś sposobem na wzbudzenie tego zaangażowania jest zapewnienie im możliwości podejmowania decyzji. Pracownik, który identyfikuje się ze swoim miejscem pracy, jest znacznie bardziej efektywny, a mając ,ojcowski” stosunek do podjętych decyzji jest bardziej gotowy do poświeceń, by zrealizować postawione cele. Partycypacja zatem w planowaniu i implementacji zmian sprzyja ich akceptacji. W organizacjach, w których stosuje się partycypację bezpośrednią, pracownicy są aktywnie angażowani w proces podejmowania decyzji. Partycypacja może być zdefiniowana jako każdy proces, który ,pozwala pracownikowi mieć wpływ na jego pracę i warunki, w których pracuje" [Strauss 1998, s. 15]. J. Wratny [2000, s. 216-217] doprecyzowuje, że przez partycypację rozumie się udział załogi w zarządzaniu firmą oparty na formule współpracy w zabieganiu o dobro przedsiębiorstwa, co pośrednio przyczynia się także do wzrostu korzyści pracowników. Towarzyszy temu założenie, że we wspólnym interesie wszyscy związani z danym przedsiębiorstwem powinni solidarnie dbać o jego utrzymanie na rynku, ponieważ w przypadku bankructwa pracę stracą i szeregowi pracownicy i kierownictwo. Możliwość współuczestnictwa i współdecydowania zachęca pracowników do zwiększenia zaangażowania oraz wzmacnia ich motywację i chęć utożsamiania się z organizacją. Zarządzanie przez partycypację ma na celu skłonienie pracowników, by nie stali się tylko biernymi wykonawcami poleceń wydawanych przez zwierzchników, ale zaangażowali się w bycie rzeczywistymi uczestnikami całego procesu. Pozwala ono także na realizowanie potrzeb wyższego rzędu, a dzięki temu zdobywania większej satysfakcji z pracy. W efekcie pracownik jest wysoce zmotywowany, związany z miejscem pracy, co przekłada się na jakość jego pracy (por. [Pawlak 2014]). J.T. Delaney i M.A. Huselid [1996] twierdzą, że w przeciwieństwie do większości innych strategii zarządzania personelem, które w dużym stopniu zależą od kontekstu organizacyjnego, zarządzanie przez partycypację jest metodą progresywną przynoszącą uniwersalne korzyści dla zwiększenia efektywności.

Podkreślić jednak należy, że zarządzanie przez partycypację może być wykorzystywane jako narzędzie manipulacji. Zwraca na to uwagę B. Kożusznik [1992, s. 103], gdy pisze, że czasem jest ono traktowane jako „środek do przekonywania podwładnych, aby zaakceptowali zmiany, które w przeciwnym razie byłyby odrzu- 
cone. Gdy za motywacją managerów do implementacji partycypacji stoi przede wszystkim przekonanie, że takie zarządzanie sprawi, że pracownicy są bardziej efektywni, możemy mieć do czynienia z przedmiotowym podejściem do pracownika, który traktowany jest jako bardziej skomplikowana maszyna, wymagająca specjalnej instrukcji obsługi, by pracowała jak najbardziej wydajnie”. Podejście takie, choć w danej sytuacji bywa skuteczne, jest sprzeczne z podmiotowym traktowaniem pracownika. Jednak patrząc długofalowo, tworzy klimat organizacyjny, który nie sprzyja współpracy, lecz raczej wzajemnym manipulacjom, brakowi zaufania i niechęci do zaangażowania. Warto przy tym przypomnieć, że brak zaufania jest jedną z przyczyn oporu przed zmianą.

Formą zarządzania partycypacyjnego, która już w samym swoim założeniu podkreśla nie tylko rolę podmiotowego traktowania pracowników, jest total participation management (TPM). Jego celem jest stworzenie takiej organizacji, której sposób działania będzie pozwalał pracownikowi na pełne uczestnictwo we wszystkich obszarach jej działalności [Stocki, Prokopowicz i Żmuda 2008]. Należy zwrócić uwagę, że różnica między TPM a zarządzaniem przez partycypację polega nie tylko na ilości (czegoś jest więcej lub mniej), ale przede wszystkim wiążącą się z nimi filozofią i rozumieniem człowieka. Podstawą TPM jest traktowanie człowieka jako osoby, która świadomie dokonuje wyborów, która potrafi określić swoje cele i dążyć do ich osiągnięcia. Człowiek zatem nie jest jedynie jednym z zasobów, przedmiotem, który wykonuje zlecone zadanie i może odgórnie być przenoszony z miejsca na miejsce, lecz osobą, która chce mieć wpływ na to, co i jak robi, a także na to, w co się angażuje [Stocki, Prokopowicz i Żmuda 2008].

Pod pewnymi względami TPM wydaje się podobne do zarządzania przez cele, jednak w TPM mamy do czynienia z szerszym podejściem do celów, które stawiają sobie pracownicy. Zdaniem R. Stockiego i współautorów [2008, s. 61] wyznaczanie celów jednostkowych powoduje, że pracownicy tylko na nich się skupiają, TPM natomiast koncentruje się na znalezieniu najważniejszego celu w danym momencie dla organizacji, a cele jednostkowe są tego pochodną. Zatrudniony więc ma wpływ nie tylko na cele związane z jego stanowiskiem, ale także na cele całej organizacji. Pozwala korzystniej dla całej organizacji ustalić cele jednostkowe oraz zmotywować pracownika do realizacji celów, które same w sobie niezbyt mu odpowiadają, ale co do których zdaje sobie sprawę, że muszą być zrealizowane, by organizacja mogła się rozwijać w ustalonym wspólnie kierunku. Zwiększa to poczucie sensu przy wykonywaniu nielubianych czynności. Zatem rozwiązania stosowane w TPM sprzyjają większej spójności celów organizacji, celów zespołu i celów jednostkowych, a także motywują do zaangażowania i rzetelniej pracy na swoim stanowisku w poczuciu uczestnictwa w większej całości.

Biorąc pod uwagę funkcjonowanie zespołu, również można dostrzec różnicę wynikającą ze stosowania TPM. Kultura pracy całej organizacji jest widoczna 
także na poziomie zespołów. Pracownik, który jest traktowany podmiotowo, z reguły stara się w podobny sposób traktować współpracowników. Wchodzi w lepsze relacje z innymi, jest bardziej skłonny do współdziałania, udzielania wsparcia oraz dzielenia się wiedzą. Poczucie kontroli i sprawczości obniżają jego stres, co sprawia, że może być on bardziej proaktywny i chętny do tego, żeby stać się samoświadomym członkiem drużyny, która będzie wspólnie pracowała, aby osiągnąć wyznaczony cel. Poczucie przynależności do sprawnie i odpowiedzialnie funkcjonującej grupy daje większe poczucie bezpieczeństwa, co z kolei zmniejsza niepokój i opór wobec zmian. Dlatego też zespół ludzi zarządzanych przez partycypację i traktowanych podmiotowo może stać się realnym sojusznikiem kadry zarządzającej w implementacji zmian. Konieczna jest przy tym jednak znajomość dynamiki procesu grupowego i praw związanych $\mathrm{z}$ funkcjonowaniem grup.

\section{Psychologiczne aspekty funkcjonowania zespołu a wprowadzanie zmian}

Grupa osób, które mają ze sobą współpracować, podlega procesowi związanemu z cyklem budowania zespołu (np. [Tuckman 1965]). Wiąże się on nieuchronnie z pojawianiem się napięć i konfliktów, które, jeśli zostaną dobrze rozwiązane, stanowić będą element drogi dojścia do wypracowania sposobów skutecznego działania. Zależeć to jednak będzie od przygotowania, otwartości i życzliwości członków zespołu, a także od kultury organizacyjnej i umiejętności menedżera (por. [Pawlak 2014]). Wdrożenie do płynnego wykonywania zadań jest ważne dla doraźnego, efektywnego funkcjonowania grupy, niemniej jednak w sytuacji konieczności dokonywania zmian może stanowić trudność związaną z nadmiernym przywiązaniem do wypracowanych wspólnie sposobów załatwiania spraw. Każda zmiana oznacza, że zespół musi w pewnym stopniu powtórzyć cały cykl, aż dojdzie do wypracowania nowych formuł działania. Jest zatem ważne, żeby konflikty i trudności nie były postrzegane jako problem, tylko naturalna kolej rzeczy i okazja do twórczego wypracowywania nowych rozwiązań.

W organizacji zarządzanej przez partycypację uprzednie wspólne ustalenie celów oraz poczucie osobistej odpowiedzialności sprawia, że grupa może szybciej przejść przez etap formowania, gdyż jej członkowie wcześniej są gotowi przedstawić swoje opinie i działać zdecydowanie, bez obawy jak zostaną ocenieni przez innych. Ponadto lepiej sobie radzą w sytuacji konfliktów, gdy łączy ich wspólny cel, a jednocześnie ze względu na kulturę organizacyjną są bardziej skłonni do wysłuchania cudzych argumentów i przekonań. Są też gotowi do zmiany dotychczas stosowanych sposobów działania na nowe, związane z wprowadzaną zmianą, w wypracowywaniu których mieli udział. 
Należy także zwrócić uwagę, że przejście przez wszystkie etapy i osiągnięcie fazy utrwalania nie oznacza, że efektywność zespołu pozostanie na stałe na wysokim poziomie. Ustalenie ról, zasad wspólnego funkcjonowania i przyzwyczajenie się do dobrej atmosfery z jednej strony prowadzi do wzrostu spójności, ale z drugiej stwarza konkretne zagrożenia dla efektywności grupy. Dbanie o dobre samopoczucie wszystkich członków oraz chęć unikania napięć i konfliktów może stać się przyczyną pojawienia się konformizmu grupowego. Powodować to może pojawienie się takich problemów, jak: przemilczane informacje, polaryzacja grupowa czy wreszcie próżniactwo społeczne, które obniżą efektywność oraz fleksybilność grupy. Poszczególni członkowie mogą cenzurować swoje wypowiedzi czy pomysły, które są sprzeczne z wypracowanymi do tej pory przez grupę rozwiązaniami, co obniża jej kreatywność i zdolność reagowania na potrzeby wynikające z pojawiających się wciąż nowych sytuacji i wyzwań. Wszystkie te procesy związane są z rozproszeniem odpowiedzialności i troską raczej o spójność grupy niż o jej wyniki.

Wzmacnianie poczucia partycypacji w sprawach firmy oraz tworzenie kultury organizacyjnej szanującej podmiotowość pracownika może w dużym stopniu pomóc uniknąć tych problemów. Jeśli członkowie zespołu czują, że rzeczywiście mają wpływ na to, co się dzieje w firmie, nie koncentrują się zbyt na zachowaniu spójności, gdyż nadrzędnym dobrem jest wspólnie ustalony cel. Wtedy nie kieruje nimi lęk związany z poczuciem braku kontroli. Ponadto podmiotowe traktowanie pracownika zwiększa jego gotowość do prezentowania swojego zdania nawet wtedy, gdy jest ono sprzeczne z opinią innych. Współuczestnictwo powoduje wzrost poczucia indywidualnej odpowiedzialności, co niweluje tendencję do próżniactwa społecznego. Zatem dzięki wzmacnianiu poczucia podmiotowości i partycypowania w sprawach organizacji jednostka, by poczuć się komfortowo w pracy, nie musi „okopywać” się na swoim znanym już stanowisku, szukając w swojej grupie sprzymierzeńców w walce ze zwierzchnikami postrzeganymi jako siły chcące zaburzyć dotychczasowy, sprawdzony już sposób działania. Wynikające zatem z podmiotowego traktowania pracowników i zaproszenia do partycypacji cechy organizacji, takie jak: przepływ informacji, troska o wzajemne zaufanie, dbanie o rozumienie interesów wszystkich, współudział w ustalaniu celów i wytworzenie atmosfery traktowania umiejętności adaptacji do zmian jako budowanie kapitału pracowniczego, pozwalają zniwelować większość wspomnianych źródeł oporu wobec zmian wymienianych przez P.F. Schlesingera i współpracowników [1999].

Ważną rolą zespołu w radzeniu sobie poszczególnych pracowników ze zmianami jest możliwość nawzajemnego wsparcia, nauki i dzielenia się kompetencjami. Aby jednak było to możliwe, zespół musi się zintegrować i spójnie funkcjonować, a jego członkowie powinni mieć okazję do tego, by poznawać się na 
kolejnych poziomach budowania relacji, czyli na poziomie zawodowym (wiedza, kompetencje, doświadczenie zawodowe, wykształcenie, preferowany sposób pracy), prywatnym i poziomie wartości. Poznanie się w grupie współpracowników w sposób naturalny zaczyna się od poziomu zawodowego, ale w celu budowania spójności ważne jest też przejście na poziom prywatny (zainteresowania, pasje, rodzina itp.), a nawet poziom wartości (czyli wyznawane wartości, sposób postrzegania świata). Podmiotowe traktowanie pracowników i promująca je kultura organizacji wpływa na ich wzajemne relacje, sprzyjając postawie wzajemnej otwartości, szacunku i prawdziwego zainteresowania drugim człowiekiem. Postawa taka sprzyja też współpracy i odpowiedzialnemu podejściu do własnych zadań bez zrzucania ich na pozostałych współpracowników, przy jednoczesnym poczuciu wzajemnego wsparcia. Dzięki temu energia i spójność zespołu może stać się sprzymierzeńcem w tworzeniu organizacji, która otwarta jest na zmiany, a jednocześnie zapewnia jednostce poczucie bezpieczeństwa i stabilizacji potrzebne do efektywnej pracy.

\section{Podsumowanie}

Współczesne rynki wymagają, aby przedsiębiorstwa stały się organizacjami stale przekształcającymi się, takimi które będą potrafiły zarówno przewidzieć kierunek nadchodzących zmian, jak i szybko się do nich dostosować. Jest to wyzwaniem zarówno dla kadry menedżerskiej, jak i dla szeregowych pracowników, u których z różnych przyczyn może pojawić się opór przed zmianami. Ich indywidualna reakcja na zmianę może być zmniejszona bądź nasilona przez oddziaływanie na siebie nawzajem członków zespołu. Dlatego znalezienie takiego sposobu zarządzania, który oprócz efektywności, zwiększa zaangażowanie, poczucie odpowiedzialności i otwartość na zmiany, jest celem wielu menedżerów. Jedną z metod zarządzania, która temu sprzyja jest zarządzanie przez partycypację. Umożliwia ono pracownikom dostęp do informacji o przyczynach, skutkach i sposobach przebiegu zmian, a przede wszystkim daje im możliwość współuczestniczenia w ustalaniu celów i sposobów działania.

Kładąc nacisk na podmiotowość pracownika, jego sprawczość i zdolność do działania, a nie tylko reagowania, zarządzanie przez partycypację wzmacnia zaangażowanie i gotowość do dojrzałej współpracy. Z kolei związane z współuczestnictwem w podejmowaniu decyzji zwiększenie poczucia kontroli pozwala obniżyć stres i lęk przed zmianą. Zmniejsza też prawdopodobieństwo wystąpienia negatywnych skutków pracy zespołowej, takich jak np. myślenie grupowe, czy budowanie wspólnych strategii przeciwstawiania się zmianie. W ten sposób zespół - zamiast jednoczyć się w sprzeciwie przeciwko konieczności wypracowywania 
nowych sposobów działania, wzmacniając tym samym opór jednostki wobec zmian - może stać się dla niej realnym źródłem wsparcia, pomagając w twórczym i efektywnym wykorzystaniu energii związanej ze zmianą.

\section{Literatura}

Blanchard K. [2007], Przywództwo wyższego stopnia, PWN, Warszawa.

Brilman J. [2002], Nowoczesne koncepcje i metody zarzqdzania, PWE, Warszawa.

Delaney J.T., Huselid M.A., [1996], The Impact of Human Resource Management Practices on Perceptions of Organisational Performance, „Academy of Management Journal", vol. 39, http://dx.doi.org/10.2307/256718.

Dudek B., Merecz D., Makowska Z. [2001], Poczucie kontroli w miejscu pracy a poziom stresu zawodowego i zwiqzane z nim skutki, „Medycyna Pracy”, $\mathrm{nr} 52$.

Folkman S., Lazarus R.S. [1980], An Analysis of Coping Behavior on a Midle-aged Community Sample, ,Journal of Health and Social Behavior”, vol. 21.

Karasek R., Theorell [1990], Healthy Work. Stress, Productivity and the Reconstruction of Working Life, Basic Books, A Division of Harper Collins Publishers, USA.

Kleiner A. [2003], Build Your Organizational Equity, ,Strategy + Business”, nr 31.

Kożusznik B. [1992], Psychologiczna problematyka autonomii i uczestnictwa, Uniwersytet Śląski, Katowice.

Kruszewska M. [2004], Zmień się albo zgiń, „Businessman Magazine”, nr 10.

Kupczyk A., Korolewska-Mróz H., Czerwonka M. [1998], Radykalne zmiany w firmie, Wydawnictwo Prawno-Ekonomiczne INFOR, Warszawa.

Lawrence P. [2008], Jak pokonać opór pracowników wobec zmian, „Harvard Business Review", nr 69, http://www.hbrp.pl/biblioteka/art.php?id=1019\&t=jak-pokonac-opor-pracownikow-wobec-zmian (data dostępu: 24.03.2015).

Pawlak J. [2014], Budowanie odpowiedzialności i integralności zespołu przez zwiększanie partycypacji pracowników w celach i zadaniach organizacji, „Nierówności Społeczne a Wzrost Gospodarczy", nr 38.

Penc J. [1998], Zarzqdzanie dla przyszłości, Wydawnictwo Profesjonalnej Szkoły Biznesu, Kraków.

Podmiotowość człowieka w organizacji [2012], red. M. Motyka, J. Pawlak, Wydawnictwo Uniwersytetu Ekonomicznego, Kraków.

Schlesinger P.F., Sathe V., Schlesinger L.A., Kotler J. [1999], Projektowanie organizacyjne, PWN, Warszawa.

Stocki R., Prokopowicz P., Żmuda G. [2008], Petna partycypacja w zarzqdzaniu, Oficyna Wolters Kluwer, Kraków.

Strauss B. [1998], An Overview [w:] Organizational Participation. Myth and Reality, eds. F. Heller, E. Pusic, G. Strauss, B. Wilpert, Oxford University Press, Oxford.

Taylor Ch. [1995], Źródła wspótczesnej tożsamości [w:] Tożsamość w czasach zmiany. Rozmowy w Castel Gandolfo, Znak, Kraków.

Toffler A. [1998], Szok przyszłości, Zysk i S-ka, Warszawa.

Tuckman B. [1965], Developmental Sequences in Small Groups, „Psychological Bulletin” vol. 63(6) http://dx.doi.org/10.1037/h0022100. 
Wratny J. [2000], Partycypacja pracownicza w perspektywie XXI wieku [w:] Praca i polityka społeczna w perspektywie XXI wieku, Instytut Pracy i Spraw Socjalnych, Warszawa.

Zbiegień-Maciąg L. [2005], Pracownik upodmiotowiony - partner społecznie odpowiedzialny [w:] Praca i zarzadzanie kapitałem ludzkim w perspektywie europejskiej, red. A. Pocztowski, Oficyna Ekonomiczna, Kraków.

\section{The Influence of Subjectivity and Employee Participation on Team Involvement and Responsibility during Times of Change} (Abstract)

Contemporary markets require companies to steadily transform, and be able to predict upcoming changes and adapt to them. The need to adapt is a challenge both for managers and ordinary employees, who may feel resistance to change. The paper discusses how strengthening employee subjectivity, and their participation, can promote acceptance of change thanks to the increased involvement and responsibility of being on a team. Any group is governed by certain stages of group development and by tendencies that affect consistency and efficiency. By stressing the importance of the worker's subjectivity, participative management reinforces his involvement, increases the sense of control and reduces the fear of change. It creates a culture at the organisation in which team members can help each other to cope with the need to change.

Keywords: participative management, involvement, team work, change implementation. 